\title{
Fungi in malting barley grain and malt production
}

\author{
Aurimas Krasauskas \\ Institute of Biology and Plant Biotechnology, \\ Aleksandras Stulginskis University, \\ Studentu 11, Akademija 53361 \\ Kaunas district, Lithuania
}

\begin{abstract}
Contamination of malting barley grain with microscopic fungi during different periods was investigated from 2012 to 2014 . Grain samples of malting barley were taken directly from the field before harvesting and from a storage silo; malted grain was taken from two malt producers in Lithuania. The fungi were isolated and identified in barley grain before the malting and after steeping and germination during the malting process. The total count of fungi was done in these barley samples during the mentioned phases. Most attention was given to widely distributed fungi known as producers of toxins: Aspergillus, Penicillium, and Fusarium. Abilities of some of these fungi to produce secondary toxic metabolites cause a possible hazard to people consuming the contaminated products.

The aim of this work was to investigate changes in fungi composition and in their total count in barley grain, the raw material for the production of malt.
\end{abstract}

Keywords: malting barley, grain, fungi, mycotoxins

\section{INTRODUCTION}

Barley is the raw material for the production of malt, and malted barley is the major raw material used in brewing of most beers and kvass. Due to its nutritive value, barley boosts the growth of various microorganisms, first of all different fungi (Angelino, Bol, 1990; Moss, 1991). Microbes greatly affect malting performance and malt quality and have a significant impact on beer quality. Depending on the nature and extent of the microbes present, their effects may be either beneficial or disadvantageous to the process and/or the final product (Flannigan et al., 1992; Jay et al., 2005). Barley may be contaminated by fungi during its growth in the field, storage, and malting (Flannigan, 2003). The activity and growth of the fungi mostly de-

\footnotetext{
*Corresponding author. Email: aurimas.krasauskas@asu.lt
}

pend on initial contamination of barley, moisture content, temperature, and aeration (Christensen, Meronuck, 1986; Moss, 1991; Pitt, Hocking, 1999).

Fungi often damage grain while it is still ripening in ears. Fungi of the Alternaria and Fusarium genera are most frequent on various grain in fields. They perish if the humidity of the nutritious substrate does not exceed 12-13\% (water activity, $a_{w}=0.65$ ) for a longer period of time. In many European countries of temperate climate, contamination of grain with the abovementioned fungi reaches $100 \%$ at the moment of harvesting. In field, fungi of the Cladosporium, Bipolaris, Botrytis, Ulocladium, Acremonium genera are recorded on ripe grain (Chelkowski, Grabarkiewicz-Szczesna, 1991; Moss, 1991).

In recent years, small grain such as barley has been greatly affected by Fusarium, primarily caused by Fusarium graminearum, leading to significant 
yield losses and quality reduction. Flannigan (Flannigan, 2003) estimated the total losses for barley and wheat due to Fusarium between 1991 and 1996 as being in the order of $\$ 3$ billion dollars in the United States alone. Another Fusarium species that causes kernel blight is Fusarium culmorum. Both F. graminearum and F. culmorum may also cause root rot, crown rot, foot rot, and stem rot in wheat and barley. Two other Fusarium species, F. poae and F. avenaceum, may also cause kernel blight in barley.

A difference as little as $0.5 \%$ in grain moisture content can be significant in microbial growth and the composition of the microbial community (Jay et al., 2005). Temperature is another important factor as the $a_{w}$, which is inherently linked to microbial growth and increases with temperature at constant moisture content of the grain. Also, Absidia, Rhizopus and Mucor fungi may develop at elevated moisture content (Flannigan et al., 1992; Moss, 1991).

Generally, storage fungi are saprophytes with low specificity, whose ability to grow and persist is mainly determined by $a_{w}$ and temperature. They comprise xerophilic members of such genera as Aspergillus, Eurotium, Micropolyspora, Penicillium, Rhizomucor (Moss, 1991).

The conditions of malting may promote activation of fungal spores that are present on/in barley seed and the growth of fungi, resulting in the synthesis of highly toxic secondary metabolites - mycotoxins (Briggs, McGuinness, 1993). During the development of barley grain, the toxigenic fungal species may synthesize mycotoxins that are accumulating in the grain. Due to their thermal stability, these toxins may be transmitted into the final product - beer, over the malting process, worth production and pasteurization (Scott, 2006).

Fusarium species have been reported as the most toxigenic fungi in northern temperate regions (Salas et al., 1999). Among storage fungi such as Aspergillus and Penicillium, Fusarium species produce mycotoxins such as trichothecenes, fusarins, moniliformin, zearalenone, and fumonisins with varying toxicological properties. Some of these mycotoxins have been associated with human and animal diseases and are known to survive the malting and brewing process. Contamination of barley with mycotoxigenic fusaria is of particular concern to both maltsters and brewers (Salas et al., 1999; Scott, 2006).

Gushing of beer is regarded as one of the most negative consequences of moulds with respect to the quality of malt and beer (Flannigan, 2003).

\section{MATERIALS AND METHODS}

Contamination of barley grain with micromycete propagules ( $\mathrm{cfu} \mathrm{g}^{-1}$ ) during different periods was investigated from 2012 to 2014. Grain samples of malt barley were taken directly from the fields of the farmers who grew barley for malt producers and from a silo; malted material was obtained from two malt producers in Lithuania. Dilution plating (surface-spread method) (Pitt, Hocking, 1999) was used for colony counting. Ten grams of each milled grain sample were homogenized in $90 \mathrm{ml}$ of sterile water. Serial decimal dilutions up to $10^{-4}$ were made and $0.1 \mathrm{ml}$ were inoculated in triplicate onto Petri dishes with media. Sabouraud glucose agar medium with chloramphenicol $\left(0.5 \mathrm{~g} \mathrm{l}^{-1}\right)$ for moulds and OGY agar for yeasts were used. The dishes were kept in thermostat at the temperature of $26 \pm 2^{\circ} \mathrm{C}$. The growing colonies of fungi were counted on days 3,5 , and 7 . Fungi were identified according to morphological and microscopic characteristics (Leslie, Summerell, 2006; Pitt, Hocking, 1999; Watanabe, 2002; Nelson, Toussoun, Marasas, 2006). The DM750 optical microscope system with the ICC50 HD camera from Leica Microsystems was used.

\section{RESULTS AND DISCUSSION}

The results indicate that fungal contamination of barley grain before and during storage may be diverse and change during the process. Additionally, the community may continue to change when malting steps change or the malt is stored and finally transported to the breweries. Analysis of microbiological contamination of grain showed that the quantity of fungi in 
grain conversion technology from the field to the malting process was increasing. The study of microbiological contamination of barley grain revealed 19 species of fungi in the grain before harvest, ten species in the grain from the storage silo, and eight species during malting.

\section{Field fungi in barley}

Field fungi invade the seeds before harvest while the crop is still in the field. Field fungi may affect the appearance and quality of seed or grain. In barley grain before storage, the number of fungi propagules was from $6.2 \mathrm{up}$ to $9.0 \mathrm{cfu} \mathrm{g}^{-1}$.

The following fungi were isolated from barley grain before storage: Acremonium strictum, Alternaria spp., Aspergillus niger, A. flavus, Botrytis cinerea, Cladosporium herbarum, Drechslera sorokiniana, Fusarium culmorum, F. poae, F. equiseti, Mucor spp., Nigrospora sphaerica, Penicillium spp., Rhizoctonia spp., Rhizopus nigricans, Stemphylium spp., Trichoderma spp., and Verticillium albo-atrum.

The isolation frequency (IF) of the most frequent fungal species (IF > 40\%) is shown in Table. Alternaria spp. were the dominant species on samples of barley grain, followed by Drechslera sorokiniana, Fusarium spp., and Cladosporium herbarum.

The dominance of certain species depended on whether the kernels were of a darker colour. While Alternaria spp. were predominant and Aspergillus spp. occurred less in darker kernels, the reverse was observed on lighter kernels where Aspergillus spp. occurred in higher frequency.
The IF of other most frequent species (Alternaria spp., Aspergillus spp., Fusarium spp. and Geotricum spp.) depended mostly on the locality the barley samples were taken from. The most frequent species associations (several fungi isolated from one sample) in grain were Alternaria spp., + Fusarium spp., Alternaria spp. + Fusarium spp. + Drechslera spp. and Geotrichum spp. + Mucor spp.

\section{Storage fungi in barley}

Storage fungi (also called storage moulds) are the fungi that invade grain or seeds during storage. Storage fungi are usually not present to any serious extent before harvest. Small quantities of spores of storage fungi may be present on grain going into storage or may be present on spilled grain present in harvesting, handling, and storage equipment or structures. Under improper storage conditions, this small amount of inoculum can increase rapidly, leading to significant problems. After harvest and before storage, barley is usually dried to a moisture content below $13 \%$.

The number of fungi propagules increased in storage conditions and fluctuated from 8.3 up to $-15.2 \mathrm{cfu} \mathrm{g}^{-1}$.

The number of fungi propagules was higher than in barley ears before the harvest, possibly because during the harvest the working elements of the combine harvester interacted with the crop and the dust rising from the soil was carried into the tank of the combine harvester together with grain. The following fungi were isolated from dried and stored barley grain:

Table. Contamination of barley grain samples with fungi

\begin{tabular}{c|c|c}
\hline Barley grain sample & $\begin{array}{c}\text { Contamination } \\
\left(\mathbf{c f u ~}^{-1}\right)\end{array}$ & Prevailing genera of fungi (IF > 40\%) \\
Barley from field & $6.2-9.0$ & $\begin{array}{c}\text { Alternaria spp. } \\
\text { Drechslera spp. } \\
\text { Fusarium } \mathrm{spp} .\end{array}$ \\
\hline Barley from a storage silo & $8.3-15.2$ & $\begin{array}{c}\text { Aspergillus spp. } \\
\text { Scopulariopsis spp. }\end{array}$ \\
Barley after malting & $18.8-22.5$ & Geotrichum spp. and other yeasts \\
& & Mucor spp. \\
& & Fusarium spp. \\
\hline
\end{tabular}


Arthrobotrys oligospora, Aspergillus niger, A. flavus, Aspergillus oryzae, Fusarium sporotrichioides, F. poae, Penicillium expansum, P. verrucosum, P. viridicatum, and Scopulariopsis brevicaulis.

\section{Fungi in barley malting}

Analysis of the samples of malted barley grain revealed that malting conditions were favourable for fungal growth. During technological processes of malting, the changes in the abundance of fungi in grain were evident.

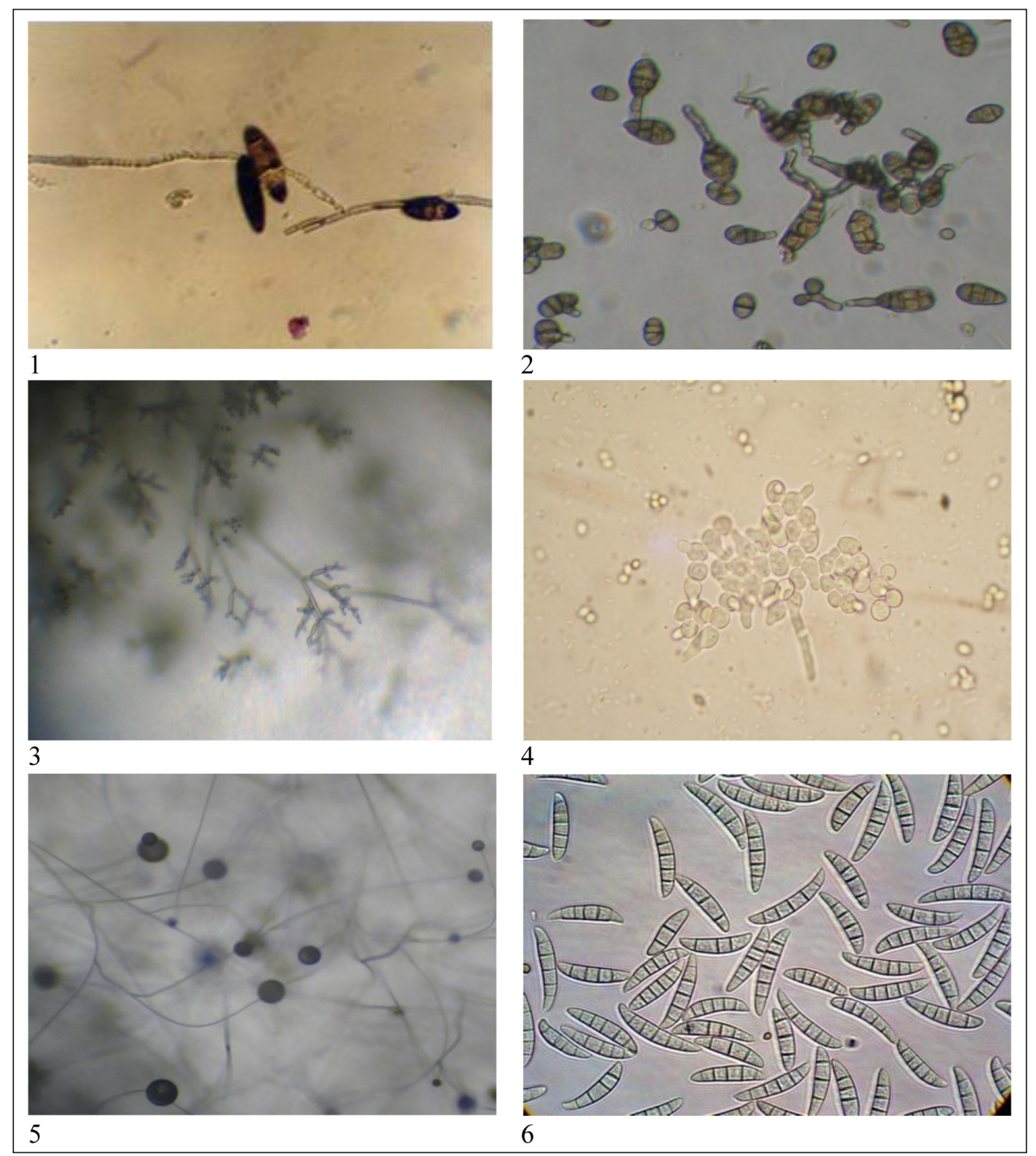

Figure. A microscopic view of the most frequent fungi in barley grain ( $\times 600$ magnification):

1. Drechslera sorokiniana; 2. Alternaria alternate; 3 . Cladosporium sp., 4. Geotrichum candidum; 5. Mucor sp.; 6. Fusarium culmorum
Technically, malting involves three steps: steeping, germination, and kilning. Steeping is the most critical step in malting with respect to both the microbial activity and microbial safety. Although some of the microbes are washed away along with the steeping water, the viable numbers increase substantially during steeping. The fungal microbiota is generally dominated by different yeasts and the most frequent is Geotrichum candidum (Figure), which prefers growth temperatures below $20^{\circ} \mathrm{C}$. 
Moreover, genus Fusarium was quite frequent as the most important group. Intensive growth of Fusarium was observed during steeping, even when the barley from the storage silo had only a low level of Fusarium contamination.

Metabolic changes in the barley kernel, including conversion of residual carbohydrates to fermentable sugars, and increase in the fungi count (observed from 18.8 up to $22.5 \mathrm{cfu} \mathrm{g}^{-1}$ ), took place during germination. The levels of some field or storage fungi such as Alternaria, Cladosporium and Aspergillus declined during germination.

\section{CONCLUSIONS}

1. Fungi of 26 kinds were isolated and identified from barley grain. These fungi belong to 16 genera. Of all isolated fungi, $15 \%$ consisted of sterile mycelium Mycelia sterilia, which on the standard used agarised mediums produced no reproductive organs. Fungi of the Fusarium genus were prevailing.

2. The quantity of fungi in grain conversion technology from the field to the malting process was increasing. Metabolic changes in barley and high water activity increase the fungi count from $6.2 \mathrm{cfu} \mathrm{g}^{-1}$ before harvest up to $22.5 \mathrm{cfu} \mathrm{g}^{-1}$ after steeping.

3. Some of the isolated and identified fungi species possessed the ability of active synthesis of toxins. The following species can be regarded as potential producers of toxins: Alternaria alternata, Aspergillus flavus, Penicillium expansum, $P$. chrysogenum, $P$. verrucosum, and others. Due to these toxins such grain loses its value and should not be used for food or feed.

Received 5 June 2017 Accepted 12 September 2017

\section{References}

1. Angelino SAGF, Bol J. Impact of microflora during storage and malting on malt properties. Raw materials and sweet wort production, Jean De Clerck Chair IV, Leuven, Belgium. 1990, 1-14.
2. Briggs DE, McGuinness G. Microbes and barley grains. Journal of the Institute of Brewing. 1993; 99: 249-55.

3. Chelkowski J, Grabarkiewicz-Szcesna J. Alternaria and their metabolites in cereal grain. In Chelkowski J, editor. Cereal grain. Mycotoxins, fungi and quality in drying and storage. Amsterdam: Elsevier; 1991. p. 67-76.

4. Christensen CM, Meronuck RA. Maintenance of quality in stored grains and seeds. Minnesota: The University of Minnesota Press; 1986.

5. Flannigan B. The microbiota of barley and malt. In Priest FG, Campbell I, editors. Brewing microbiology. 3rd edition. New York: Kluwer Academic/Plenum Publishers; 2003. p. 113-80.

6. Flannigan B, Okagbue RN, Khalid R, Teoh CK. Mould flora of malt in production and storage. Brew Distill Int. 31 (1982).

7. Jay JM, Loessner MJ, Golden DA. Modern food microbiology. New York: Springer; 2005.

8. Leslie JF, Summerell BA. The Fusarium laboratory manual. Iowa: Blackwell Publishing; 2006.

9. Moss M. Mycology of cereal grain and cereal products. In Chelkowski J. editor. Cereal grain. Mycotoxins, fungi and quality in drying and storage. Amsterdam: Elsevier; 1991.

10. Nelson EP, Toussoun AT, Marasas OF. Fusarium species. An illustrated manual for identification. University Park and London: The Pennsylvania State University Press; 2006.

11. Pitt JI, Hocking AD. Fungi and food spoilage. 2nd edition. Chapman and Hall; 1999.

12. Salas B, Steffenson BJ, Casper HH, Tacke B, Prom LK, Jr. Fetch TG, Schwarz PB. Fusarium species pathogenic to barley and their associated mycotoxins. (10) Plant Dis. 1999; 83: $667-74$.

13. Scott PM. Mycotoxins transmitted into beer from contaminated grains during brewing. J. AOAC Intl. 2006; 79(4): 875-82.

14. Watanabe T. Pictorial atlas of soil and seed fungi. Morphologies of cultured fungi and key to species. 2nd edition. CRC Press LLC; 2002. 


\section{Aurimas Krasauskas}

MIKROSKOPINIAI GRYBAI SALYKLINIUOSE MIEŽIUOSE IR SALYKLO GAMYBOJE

\section{Santrauka}

2012-2014 m. atlikti salyklinių miežių grūdų taršos mikroskopiniais grybais tyrimai derliaus nuėmimo ir skirtingais perdirbimo etapais. Subrendę miežių grūdai tyrimams buvo paimti iš lauko prieš derliaus nuèmimą, iš grūdų saugyklos, taip pat iš dviejų Lietuvos salyklo gamintojų paruoštų šviežio salyklo grūdų. Mikroskopiniai grybai buvo išskirti bei identifikuoti miežių grūduose prieš salyklo gamybą ir salyklo gamybos etapuose (po mirkymo ir daiginimo), nusta- tytas grybų pradų skaičius miežių grūdų mėginiuose visuose minètuose etapuose. Daugiausia dèmesio miežių salyklo gamintojai ir naudotojai turètų skirti salyklinių grūdų taršai tokiais plačiai paplitusiais mikroskopiniais grybais kaip Aspergillus, Penicillium ir Fusarium, kurie išskiria mikotoksinus. Kai kurių iš šių genčių grybų gaminami antriniai toksiški metabolitai sukelia potencialią toksikozès riziką žmonėms, vartojantiems mikotoksinais užterštus produktus.

Šio darbo tikslas buvo ištirti mikroskopinių grybų sudèties pokyčius ir jų bendrą skaičių salyklinių miežių grūduose - salyklo gamybos žaliavoje.

Raktažodžiai: salykliniai miežiai, salyklas, mikroskopiniai grybai, mikotoksinai 